\title{
Impacts of Mobile Technology on Nigeria Broadcasting Communication Policy
}

\author{
I. W. Udomisor ${ }^{1}$, S. P. E. Akoje ${ }^{2} \&$ Emem I. Udomisor $^{3}$ \\ ${ }^{1}$ Associate Professor, Department Of Mass Communication University Of Maiduguri, Borno State Nigeria. \\ ${ }^{2}$ Graduate Fellow Department Of Mass Communication University Of Maiduguri, Borno State Nigeria. \\ ${ }^{3}$ (MLS) Ramat Library, University Of Maiduguri, Borno State, Nigeria. \\ Correspondence: I. W. Udomisor, Department Of Mass Communication University Of Maiduguri, Borno State Nigeria.
}

Received: November 10, 2014

Accepted: November 26, 2014 Available online: December 26, 2014

doi:10.11114/ijsss.v3i1.624

URL: http://dx.doi.org/10.11114/ijsss.v3i1.624

\begin{abstract}
The broadcast media of communication in Nigeria has witnessed changes over the years. It started as strictly a state controlled media based on the assumption that the airwave is a public commodity that must be orderly utilized. But after the deregulation of the industry, additional restrictions on the use of the media became necessary and these became part of Nigeria broadcasting communication policy (or code) guiding the conduct of broadcasters. This paper explores instances of apparatus contradictions and circumstances of Nigeria broadcast communication policy with the emergence of Mobile Communication Techonology. However, using both structural conflict and structural functionalist approaches in the analysis of this subject, this paper concludes that there are both conflicting and functional impacts of the new technology on Nigeria broadcasting and communication policies guiding its operation. Therefore, as conflicts and functions characterize social changes, these impacts are unimportant if Nigeria is to develop.
\end{abstract}

Keywords: Communication Policy, Broadcast Media, Mobile Phones, Technology, Global System.

\section{Introduction}

Communication is another pervasive aspect of human cultural heritage. In fact, the socialization process through which a person gets acquainted with the norms, values and mores of a given society is a communication process. Within any society, there are principles that define how this process works. These principles are often traceable to the religious norms, values and mores of that society, traditiaonal or modern.

The business of communication is very crucial, if left without a set of guiding principles even at individual level, the consequences can be disastrous. Also, the plurality in modern societies calls for policies to guide interpersonal, group and mass communicaton to mimimize clash of interest and ultimately, societal conflict. Today, conflicts of various kinds abound in Nigeria, espcially in religious circle.

The above observation agrees with the position of communication scholars when they say that: 'no communication, no society' (Kunczik, 1984:25). In this direction, the developments of human societies small or big, are hinged on communication and the level of free access to information from the people to the government and vice-versa. This is very important especially in a democratic setup like Nigeria in the last one decade. This importance was highlihted by Mu'azu (2010), when he argued that information is needed to enable the citizenry participate in their governance by making decision from an informed position.

The importance of communication and access to information in devleopment was recognized by United Naiton Education, Scientific and Cultural Organization (UNESCO), when it was discovered that the concept of "free flow" of news and information between developed and developing or underdeveloped nations of the world was at best a "one-way flow". That is, from the developed nations to the developing ones with a dependency and underdevelopment implications (McBride, 1980; Murtala, 1991; Smith, 1980; Schiller, 1976).

As a result, UNESCO organized series of international conferences to address issues on policies that nations of the world (especially the developing nations) needed to pursue with respect to communication especially communication via the modern mass media and its numerous technologies. Starting with the 1976 conference on communication policies in San Jose de Costa Rica, it was agreed that communication in today's world has become a permanent factor of national renascence and as a powerful force in international relations. A call was made to nations of the world, 
admonishing individual nation-states to pursue national communication policies conceived within the context of national realities and hinged on free expression of thought and balanced with respect for individual and social right and freedom as enshrined in the UNO Universal Declaration of Human Rights of 1948 (Murtala, 1991:85; Udomisor, 2010).

In UNESCO's conference on communication in Paris, France, the then Director General of UNESCO, Amadou-Mahtar M'Bow constituted a 16-man team to act as international commission on communication and Sean McBride of Ireland was appointed its chairman. The commission was mandated to study all communication problems in the human society. One specific mandate that concerns us here was to make inquiry into the growth impact and repercussion of technological progress in the field of communication (Mc Bride, 1980; Murtala, 1991:87).

In answer to the call based on the recommendations by the Mc Bride Commission Report, Ray Udeajah, (2004:8-14) stated that the first National Mass Communicaiton Policy Conference (NMCP)in Nigeria was held in Badagry in 1987. During the conference that lasted for days of 12 sessions, 52 commissioned papers were presented and was later documented in two volumes and entitled: Philosophy and Dimensions of National Communication Policy. One question raised in the conference of policy direction was 'how Nigeria can improve its obsolete, analogue telecommunicaiton system' (Murtala, 19991:91).

One of the papers, presented by Adekola, (1987), suggested that this can be done through a highly digitalized telecommunication network service called Intergrated Service Digital Network (ISDN). He espoused the virtues of ISDN to the conference participants.

Further to this, he posited that the services of ISDN would improve not only NITEL facilities, but also the Nigeria Postal Services (NIPOST), television stations, radio stations, print media and ministry of information.

The impact of the virtues of ISDN can be seen today to a large extent in the operation of Global System of Mobile Communication (GSM) in Nigeria since 1999 when it was introduced. Today, Nigeria can boast of a highly competitive mobile telecommunication in this electronic age. These include, MTN, Global Com, Zain, StarCom, Visafone, Etisalat and Retel.

\section{Scope and Limitation}

In social analysis, it will be a misrepresentation of reality and academic arrogance to claim to have answer to all social questions with regard to a given topic. Thus, this paper does not in any way claim to present an exhaustive instances and analysis of impacts of mobile techonology on Nigeria broadcast communication policy.

\subsection{Aim of the Paper}

The aim or objecitve of this paper was to explore the various ways in which mobile telecommunication introduced in Nigeria to improve the telecommunication sector in 1999 has impacted on broadcast communication policy in the country. This is especially as it relates to Nigeria Broadcasting code and the use people, including journalists make of the technology.

\section{Definition of Terms}

\subsection{Mobile Technology}

Probably the most useful thing to know about the Global System for Mobile communications (GSM) is that it is an international standard.Information obtained from [www.beginnersguide.com] says that if you travel in Europe and many other parts of the world, GSM is the only type of celluar service available. Originally, the acronym GSM stood for Group Special Mobile, a group formed by the Conference ofEuropean Posts and Telegraphs (CEPT) in 1982 to research the merits of a European standard for mobile telecmmunications. Commercial service using the GSM system did not actually start until 1991. Instead of using analog services, GSM was developed as a digital system using TDMA technology.[www.beginnersguide.com]

Using TDMA, a narrow band that is $30 \mathrm{kHz}$ wide and 6.7 milliseconds long is split time-wise into three time slots. Narrow band means channels in the traidtional sense. Each conversation gets to radio for one-third of the time. This is possible because voice data that has been converted to digital information is compressed so that it takes up significantly less transmission space. Therefore, TDMA has three times the capacity of an analog system using the same number of channels.[www.beginnersguide.com]

TDMA is the access method used by GSM, as well as the Electronic Industry Alliance and the Telecommunicaiton Industry Association for Interim Standard 54 (IS-54) and Interim Standard 136 (IS-136). GSM implements TDMA in a somewhat different and incompatible way from IS-136. Think of GSM and IS-136 as two different operating systems that work on the same processor, like Windows and Linux both working on an Intel Pentium III (www.beginnersguide.com). 
GSM (Global System for Mobile Communication) is a digital mobile telephony system that is widely used in Europe and other parts of the world. GSM uses a variation of time division multiple access (TDMA) and is the most widely used of the three digital wireless telephony technologies (TDMA, GSM, and CDMA). GSM digitizes and compresses data, then sends it down a channel with two other streams of user data, each in its own time slot. It operates at either the $900 \mathrm{MHz}$ or $1800 \mathrm{MHz}$ frequency band.[www.searchmobilecomputing.com]

Mobile services based on GSM technology were first launched in Finland in 1991. Today, more than 690 mobile networks provide GSM services across 213 countries and GSM represents $82.4 \%$ of all global mobile connections. According to GSM World, there are now more than 2 billion GSM mobile phone users worldwide. GSM World references China as the largest single GSM market, with more than 370 million users, followed by Russia with 145 million, India with 83 million and the USA with 78 million users.

Since many GSM network operators have roaming agreements with foreign operators, users can often continue to use their mobile phones when they travel to other countries. SIM cards (Subscriber Identity Module) holding home network access configurations may be switched to those that will metered local access, significantly reducing roaming costs while experiencing no reductions in service.

GSM, together with other technologies, is part of the evolution of wireless mobile telecommunications that inlcudes High-Speed Circuit-Switched Data (HCSD), General Packet Radio System (GPRS), Enhanced Data GSM Environment (EDGE), and Universal Mobile Telecommunications Service (UMTS] (www.searchmobilecomputing.com)

Since GSM is connected in a cellular network, mobile phones can connect to the system by way of cells that may be in their area. GSMs usually operate using four radio frequencies: $850 \mathrm{MHZ}, 900 \mathrm{MHz}, 1800 \mathrm{MHz}$, and $1900 \mathrm{MHz}$. also GSMs use four cell sizes: macro, micro, pico, and umbrella. The macro cells are normally referred to as cells that have the base station antenna installed on some kind of mast or on the building somewhere. So if you see an antenna on top of a building, this may be the macro cell. The micro cell is considered the antenna that is installed below the roof. These types are usually found in urban areas. Pico cells are basicially found inside buildings. The umbrella call is used to cover smaller cells and help fill in gaps in coverage where the smaller cells can't reach.

So how does it work? [ www.howstuffworks.com] says that when a customer places a call using his/her cell phone, GSM uses a process called circuit switching. This method of communication allows a path to be established between two devices. Once the two devices are connected, a constant stream of digital data is relayed. This allows the receiving end to hear the data being sent before the whole message or data was finished. The advantage to this is there's no waist of time .(www.howstuffworks.com).

\subsection{Communication}

Communication is such a wide area that it would be near impossibility to examine the various ways in which it is influenced by religion. Hence, in this paper, communication will refer specificially to mass communication communication through Newspaper, Magazine, Radio and Television. This thus excludes: interapersonal, interpersonal, gorup communications, telephony, fax, etc. Communication involves the sharing of messages, ideas, or attitudes resulting in a degree of understanding between the sender and the receiver. In fact, the term 'communication' is an all embracing process by which people share information, ideas, and feelings. It involves the deliberate use of either spoken, written words and other non-verbal kinesics behavior such as body language, gesture, personal mannerism/style and the immedate physical environment which add meaning to a particular message or information (Ndidi, 2005; Lewis, 1975).

\section{Policy}

A policy is a plan or course of action designed to define issues, influence decision-making, and promote broad objective of an individual, groups, or government. Put differently, it is a deliberate plan of action to guide decision and achieve rational outcome(s) (Paquette, 2002; Althan et al, 2007).

The term 'policy' is not normally used to denote what is actually done. This is referred to as 'procedure' or 'protocol'. A policy contains: the "what and why", procedures or protocols; "the what, the how, the where, and the when" about the phenomenon upon which the formulation of the policy is based. Policy may refer to governments, private sector organization, groups, and individuals. Hence, presidential executive orders, corporate privacy policies and parliamentary rules or order are examples of specific policies (Paquette, 2002).

Broadly speaking, policies are instituted to avoid some negative effects that has been noticed in an organization or in a particular society or to seek some positive benefits. Thus, policies can be understood as a political, a management, financial or an administrative mechanism arranged to reach explicit goals (Howard, 2005; Jenkins, 1975). 


\subsection{Communication Policy}

Communication policy is the conjugation of two concepts - communication and policy. By communication policy, reference is made to a set of principles and norms established to guide the behaviour of communication system. They are shaped over time in the context of society's general approach to communication and the media; emanating from ideology, social and economic conditions of the country and the values on which they based (Udomisor, 2009).

Policy formulation is not pecular to communication or mass communication alone, rather it is a global socio-political and eocnomic phenomenon. In fact, in any social polity like ours, there are different types of policies in operation. These may include: communication and information policy; defense policy; domestic policy; economic policy; education policy; energy policy; environmental policy; foregin policy; health policy; housing policy; human resource policy; micro economic policy; monetary policy; population policy; privacy policy; public policy in law; transportation policy; water policy; etc.

The ultimate source of the aforementioned social policies in Nigeria is the constitution. With reference to communication, chapter two, "Fundamental Objectives and Directive Principles of State Policy" of the 1999 Constitution of the Federal Republic of Nigeria in section 22 provides that: "The press, radio, television, and other agencies of the mass media shall at all times be free to uphold the fundamental objectives contained in this chapter and highlight the responsibility and accountability of the government to the people".

From this constitutional provision, the national mass communication policy is generally granted a foot hold and formalized. It is now left in the hand of the Federal Ministry of Information to formulate and concretize the policy in a document, providing specific directives to the different Television, Public Relations and other information organizations.

In the international arena, global communication policies are traditionally made in such intergovernmental forum such as United Nations Educational, Scientific and Cultural Organization (UNESCO); the World Intellectual Property Organization (WIPO) and the International Telecommunication Union (ITU). These organizations are relatively open to the socio cultural dimension in information and communication technologies.[Hamelink,2002] Moreover, the New World Information and Communication Order (NWICO) debate in the 1970s and 1980s, among other things demanded for the establishment of national communication policy in each nation of the developing world.

In Nigeria under the present democratic dispensation, there is no single communication policy document that spells out the functions and operation of the different mass communication typologies. A document of such nature which was inherited from the military era has its provisions overtaken by time and events (Udeajah, 2004; Udomisor, 2009). So, with the restoration of democracy in Nigeria since 1999, the nation is due to have a well documented mass communication policy to guide specific mass media operation with goals that are development oriented and based on democratic ideals. Yet, it has been our experience that after many years of democracy, such a document has not yet materialized. This situation continues to persist despite all the cries about development, digitization of the broadcast media and the rebranding of Nigeria image abroad. The federal ministry of information has not yet been able to formulate a concise mass communication policy for the nation.

\subsection{Theoretical Framework}

In every academic pursuit, theories are of tremendous value. This is because they lend themselves to a vast array of tests and analysis, as the subject matter of research gets explained, clarified and even predicted. The exploration of this paper derives its theoretical justification from the Structural Functionalist and Conflict theories.

The Structural Conflict theory has two sub-orientations-the radical structural conflict theory advanced by Marxists' dialectical school and the liberal structural conflict theory. The theory sees incompatible interests in the society as the basis for competition for resources, which are often scarce. This situation leads to conflicts and social advancement is seen by conflictists as characterized by competition rather than harmony. The main argument of the theory is that conflict is built into the particular ways societies are structured and organized. It looks at social problems such as political upheavals, economic exclusion, injustices, poverty, diseases, exploitation, inequality, etc as sources of conflicts. Hence, such conflicts lead to social change. The theory argued that, rather than a harmonious working of the various parts of the institutions of the society, it is the competitive nature of societies that determine development. (Coller, 2002); Faleti, 2007; Haralambos and Heald, 1980).

The structural conflict theory is necessary in understanding how some communication policies in Nigeria Broadcasting Code are contradicted through the use of mobile communication technology in some specific areas.

The second theory is the structural functionalist theory of the society in relation to institutions and their functions within Nigeria social system. According to Dennis Mc Quail (2005:75), structural functionalism tends to explain social practice and institutions in terms of the needs of the society and individuals. In this approach, society is viewed as an 
ongoing system of linked working parts or subsystems (in this case educational and research institutions inclusive), with each making essential contributions to the continuity and order in the society. Organized social life is said to require the continued maintenance of more or less accurate, consistent, supportive and complete interrelated working of the society and its environment. The theory further assumes that it is by responding to the demands of individuals and institutions in a consistent ways that each institutional benefits are made accruable to the whole society (Folarin, 1998; Haralambos and Heald, 1980).

The structural functionalism approach is based on the organist paradigm and sees the society as a systemic, interrelated, interdependent, evolving, equilibrium-oriented whole, representing underlying system's needs and functions. The structural functionalist analysis is suited for analysis of adaptive structure or process (research, in this case), because this method places currently variable's behavior (functions) in relation to an assumed stable system (structure) characterized by certain needs and mechanism (Kinlock, 1977:190; Kunzick, 1984:156).

The Structural Functionalist theory is relevant to the understanding of the functional roles of mobile communication technology in furthering and enhancing the performance of broadcast, radio and television, in Nigeria.

\section{Statement of the Problem}

With the inception of broadcasting as another means of communication, national and international governments have perfected policies aiming at regulating and controlling the use of broadcasting tools in disseminating information. Some countries have established specific agencies charged with the duty of formulating rules, laws and policies to guide and regulate how the broadcast media are put to use. This is done to ensure a harmonious working of the system to bring about growth, development and progress. Most of the policies formulated by nations particularly developing nations affect television, radio and video disc as well as broadcast advertising. In Nigeria, the National Broadcasting Commission is placed in charge of this responsibility. With the coming of a new way of communication, that is the use of mobile phones there is no specific policies formulated to guide and regulate the use of mobile phone in communication. There are scanty studies on the introduction and impact of mobile phones in the society but there is no study dealing with the regulation of mobile phones in the society. There is no study seeking to find out how the use of mobile phones in communication violates policies established to guide broadcasting as a means of sending and receiving information and messages via the air waves.

\subsection{History of Mobile Phone and Its Uses in Nigeria}

When Nigeria gained independent in 1960, there were only 18,724 functional telephone lines for an estimated population of 45 million inhabitants. This translated into a 'teledensity' ratio of 0.04 telephones per 100 people. During the period of military rule in Nigeria, little or no attention was accorded the development of the telecommunication sector.

In 1992, the Nigerian government through decree No. 72 of December $31^{\text {st }}$ established the National Communication Commission (NCC) and empowered it with the duty of formulating strategies and policies to ensure effective and rapid development of the telecommunication sector as Nigeria's telephone density and penetration remained poor.

A survey by the International Telecommunication Union in Nigeria in 1996 showed that Nigeria's teledensity ratio rose to a meager 0.4 by 1999 . The Nigerian Communication Commission, an agency charged with the responsibility of regulating the activities of service providers lamented that the average of 1.67 was nothing to write home about. The Nigerian Communication Commission admitted that Nigeria's telephone network operated by NITEL which was established in 1985 with an exclusive monopoly of the sector was severely limited. Those who applied for telephone lines either for personal or business use were over 10 million on the waiting list. Admittedly business promotion and cultural development were adversely affected.

In the year 1991, Nigeria's telecommunication sector witnessed a dramatic change with the introduction of GSM mode of communication into the country as Nigeria's teledensity ratio tripled within one year of GSM operation. By 2005, Nigeria with an estimated population of 128,771,988 inhabitants had more than 9 million GSM subscribers, making the country one of the fastest growing GSM markets in the world. By the year 2008, statistics revealed that out of Nigeria's 49 million telephones subscribers less than twenty million users were actually connected.

By May 29, 1999, the administration of President Olesegun Obasanjo deregulated the Nigerian Telecommunication sector by granting licenses to GSM service providers and embarking on the privatization of NITEL, MTN, CELTEL (AIRTEL) and GLOBACOM. 
Internet Usage and Population Growth

\begin{tabular}{llllr}
\hline Year & Users & Population & $\%$ Pen & Usage Source \\
\hline 2000 & 200,000 & $142,895,600$ & $0.1 \%$ & ITU \\
2006 & $5,000,000$ & $159,404,137$ & $3.1 \%$ & ITU \\
2009 & $23,982,200$ & $149,229,090$ & $16.1 \%$ & ITU \\
2011 & $45,039,711$ & $155,215,573$ & $26.5 \%$ & ITU \\
\hline
\end{tabular}

Source: Internet World Stats > Africa > Nigeria.

There are several advantages in the deregulation of the telecommunication sector and the introduction of GSM technology into the country. The introduction of GSM has accelerated the speed of economic development as it has provided the needed stimulus to promote trade between Nigeria and her trading partners. Tribune newspaper of July 16 , 2004 indicated that the Nigerian government treasury was boosted through payment of over 200 billion naira taxes and levies by service providers.

With the deregulation of the telecommunication sector, national productivity became enhanced while communication became highly improved which led to narrowing the gap between the Urban and Rural dwellers. Most Nigerians use their GSM phones to communicate with one another. It is a well-known fact that students used the GSM phones to communicate with their course mates, friends, lecturers and family relatives. Mobile phones limit the need for students to travel and also facilitate the exchange of information whenever the need arises. Ndukwe (2004) explains that close to 2000 persons have been directly employed by GSM operators while an estimated 400,000 Nigerians are benefiting from indirect employment by GSM service providers in the country.

Today one can positively say that the introduction of mobile phones into the country has created a positive and significant impact on economic growth. In Africa, Nigeria inclusive, the number of mobile phone users is growing very rapidly to the extent that Africa and Nigeria inclusive has now become the fastest growing mobile phone market in the world.

\begin{tabular}{llll}
\hline Total telecom connections & $93,461,436$ & $107,367,095$ & $100 \%$ \\
Fixed/Fixed Wireless & 801,297 & 474,345 & $0.4 \%$ \\
Sub-total (CDMA) & $5,215,131$ & $3,239,370$ & $3 \%$ \\
Sub-total (GSM) & $87,417,508$ & $103,653,380$ & $96.5 \%$ \\
Total Wireless & $92,632,639$ & $106,892,750$ & $99.6 \%$ \\
Subscribers by operator in September 2011 and 2012 & & \\
Operator & Subscribers In Sept 2011 & Subscribers In Sept 2012 & Share of mobile market \\
MTN Nigeria & $41,107,494$ & $45,639,749$ & $42,7 \%$ \\
Communication & & & \\
Globacom Limited & $19,854,111$ & $22,260,822$ & $20.8 \%$ \\
Celtel Nigeria Limited (Airtel) & $16,683,946$ & $21,101,758$ & $19.7 \%$ \\
EMTS Limited (Etisalat) & $9,513,437$ & $14,392,531$ & $13.5 \%$ \\
Other mobile including CDMA & $5,473,651$ & $3.497,890$ & $3.3 \%$ \\
Type & 2011 & 2012 & $\%$ \\
\hline Source: NCC, Sept 2012 & & Via:mobiThinking &
\end{tabular}

\subsection{Demerit of Cell Phone Usage in Nigeria}

For one to be able to access the internet via mobile phones though interesting and encouraging is gradually becoming a major reason for concerns. The situation becomes more worrisome particularly because internet content is not thoroughly and effectively censored and regulated. Personal blog pages, chat rooms, emails, web sites and search programmes could contain pictures and texts with pornographic information and messages. Cellular phones have the ability to transmit textual and pictorial information in form of texts, graphics, phonographs, video clips and audio records. Communication scholars believe that mobile phones are very effective devices for communication. 


\begin{tabular}{|c|c|c|c|}
\hline \multicolumn{4}{|c|}{ Device Manufacturer Market Share In Nigeria (Statcounter) Most Popular Handsets In Nigeria (Opera) } \\
\hline Device manufacturer & Market share & Rank & Top 10 handsets \\
\hline Nokia & $74.5 \%$ & 1 & Nokia $\mathrm{Cl}$ \\
\hline Samsung & $4.2 \%$ & 2 & Nokia X2-01 \\
\hline LG & $1.8 \%$ & 3 & Nokia 2700c \\
\hline RIM & $1.5 \%$ & 4 & Nokia C3 \\
\hline Sony Ericsson & $1.1 \%$ & 5 & Nokia 5130 XpresssMusic \\
\hline Apple & $0.8 \%$ & 6 & Nokia C2 \\
\hline HTC & $0.5 \%$ & 7 & Nokia N72 \\
\hline Huawei & $0.3 \%$ & 8 & Nokia 2690 \\
\hline T-Mobile & $0.1 \%$ & 9 & Nokia 2330c \\
\hline Unknown & $15 \%$ & 10 & Nokia 200 \\
\hline
\end{tabular}

Doreen (1993) says that the new technology of mobile phones has created a situation of 'any way differentiated mobility' the global population of youths within the age brackets of 14-35 years constitute an estimated 1.52 billion, about $19.3 \%$ of the people on earth. With this estimated population of youths, there is no doubt that the ownership and usage of mobile phones has created an 'anyway-differentiated mobility' of this technological generation. While some of them are more in charge of their phones and their influence on them, others are more strongly imprisoned by these technological gadgets.

\begin{tabular}{ll}
\hline \multicolumn{2}{l}{ How Nigerians use their mobile phones } \\
\hline Mobile phone use & Proportion using \\
SMS & $44 \%$ \\
Gaming & $16 \%$ \\
Music & $14 \%$ \\
Email & $2 \%$ \\
Social Networking & $2 \%$ \\
Internet & $2 \%$ \\
Location & Less than 1\% \\
\hline Source: TNS Mobile Life & via. mobiThinking
\end{tabular}

Social scientists today are claiming that those technological revolutions are driving the society at an uncontrollable speed.

The relationship between technology and society they say is linear and mono-directional, without a well-thought-out remedial action by both the industry and government. They are saying that, the new inventions would bring about a defector repeal of existing telecommunication surveillance authority conferred upon law enforcement agencies.

\subsection{Uses and Application of Mobile Phones by Youths.}

The emergence of mobile phones in Africa and Nigeria would have been a good vision for Nigeria. Far beyond expectation, a significant percentage of Nigerian youths seem to develop an inclination to the use of mobile phones in such a way that may affect the society negatively. This has blurred the positive vision of the new technology that would have provided hope for a better future.

While very few young children in our various societies may be making good and judicious use of mobile phone, a great majority are using the access for issues that are demoralizing and embarrassing.

Many of our youths including some adults use mobile phones for sexting, phonography and internet fraud.

In much the same way as radio and television broadcasting are regulated for positive use in the society, the use of mobile phones should equally be subjected to government control and regulation. The agency in Nigeria established to regulate the use of the air waves is the National Broadcasting Commission. The National Broadcasting Commission has formulated codes, rules and regulations aimed at controlling how the airwaves is used. Is the use of mobile phones 
affected? How does the use of mobile phones by youths in the society violate the broadcasting codes in Nigeria?

\subsection{The National Broadcasting Commission Regulations}

The National Broadcasting Commission, having been empowered by decree No. 38 of 1992 has formulated code of conduct to guide and direct the operations of broadcasting in Nigeria. The code of conduct for broadcasters covers the following broad areas, broadcasting standard, programmes, news and current affairs, party, political programme, sports and outside broadcast, advertising, sponsorship and infomercials, community and network broadcasting, reporting procedure and sensations.

However this study takes a look at the regulations as it affects sex and pornography, obscenity and indecent advertisement particularly as they affect youths in the society. It also takes a look at regulations as they affect advertising using the airwaves.

Section 2 of the National Broadcasting Code of 1993 dealing with programming standard and requirements in its sub-section 2.2.2. (a) and (b) already stated that obscene or vulgar language expressions, presentations and representation that are pornographic are forbidden. The security of marriage and family life shall be promoted and strictly upheld. The revised edition of the broadcasting code of 2006, section 4.3.1 and 4.3.2 (a) (b) (c) says that children and young persons are particularly vulnerable to influence and therefore needs protection from broadcast materials likely to lead them into anti-social behaviors. Station shall not broadcast a programme containing sexually explicit or obscene material and stations must avoid the use of blasphemous language.

Relating to advertising using the airwaves, the 1993 broadcasting code section 4.3 paragraph 21, 22, 25, 27 says that no advertisement shall be calculated to play on fear to induce people to purchase the article or service. No advertisement shall contain any misleading descriptions, claims or illustrations directly or indirectly or by implication about the product or service being advertised. No advertisement of a product or service shall be accepted which purports to increase sexual virility or correct sexual weakness. Section 4.3 (27) of the broadcasting code also states that lawful advertising of or organisations which conduct award winning competitions or legalized lotteries is acceptable provided such advertising does not extort the public or unduly exhort them to engage in betting.

\subsection{National Broadcasting Commission, Mobile Phones and the Law}

In Nigeria the impact of mobile technology and that is the introduction of mobile phones as a modernized way of communication seems to be greater in the social aspect of the society. Information bordering on obscenity, bestially, vulgarity, pornographic representation, homosexuality lesbianism and incest are class 'A' and 'B' offences that broadcasters are warned against. But, with the introduction of mobile phone in Nigeria, these problems become pervasive as even children of basic school age acquired mobile phones and therefore have free and unhindered access to materials on pornography in pictures and video clips which are electronically transferred using mobile phones. These are some of the information and data that Nigerian broadcasters are prohibited from transmitting via the airwaves.

Again, the Nigeria broadcasting code, chapter seven treated issues relating to advertisements and the role of Advertising Practitioners Council of Nigeria (APCON) in ensuring that advertisements are clearly stated. With the inception of mobile phones in Nigeria in 1999 a new advertising outlet seems to develop with no law stating how APCON can regulate it. To find out more about this problem a field study was considered inevitable.

\subsection{Data Presentation and Analysis}

To find out, the penetration, use and effects of mobile phone usage among youths in the society a total of five hundred questionnaires were designed and distributed among respondents. The study population constituted of students of four faculties of the University of Maiduguri. Selection of faculty represented was done through purposive sampling where Faculty of Social Sciences, Faculty of Arts, Faculty of Education were picked. Out of the total student population of these faculties four hundred students were randomly selected and used for this study.

Out of the four hundred questionnaires distributed, three hundred and seventy were returned suitable for this study. The results are presented in the tables below.

Table 1.

\begin{tabular}{lcc}
\hline Age range & Frequency & Percentage \% \\
\hline 14-20 years & 100 & 27.1 \\
21-27 years & 120 & 32.4 \\
28-35 years & 150 & 40.5 \\
Total & $\mathbf{3 7 0}$ & $\mathbf{1 0 0 . 0 0}$ \\
\hline
\end{tabular}


Table number 1 above shows the age grade of respondents used in the study. The above results have shown that respondents in the age grade of 28-35 years were on the majority (40.5) followed by the age grade of 21-27 years with $32.4 \%$. The remaining $27.1 \%$ were in the age grade of between $14-20$ years.

Table 2. Mobile Phone Penetration

\begin{tabular}{llcc}
\hline & Responses & Frequency & Percentage \% \\
\hline Own a mobile & Yes & 370 & $100.0 \%$ \\
Own a phone & No & 00 & $00.0 \%$ \\
Total & & 370 & $100.0 \%$ \\
\hline
\end{tabular}

Out of the total number of respondents interviewed none claimed that he or she did not own a mobile phone. All the respondents claimed to be proud owners of mobile phones with multiple SIMS in them.

Having seen how mobile phone was popular among youths, it became necessary to find out the models of mobile phones used by them.

Table 3. Mobile Phone Models

\begin{tabular}{lcc}
\hline Phone Models & Frequency & Percentage \% \\
\hline Nokia & 100 & 27.0 \\
Blackberry & 55 & 14.8 \\
Techno & 60 & 16.2 \\
Samsung & 65 & 17.6 \\
Sony Ericson & 50 & 13.5 \\
Apple & 10 & 02.7 \\
Motorolla & 10 & 02.7 \\
Hanwei & 15 & 04.1 \\
Sagem & 05 & 11.4 \\
Total & 370 & 100.0 \\
\hline
\end{tabular}

Facilities found in respondents phone which greatly aided communication and sharing of data in all forms include, MMS, SMS, Bluetooth, Camera and Internet modem.

Table 4. Respondents, Mobile Phones and Internet Connectivity

\begin{tabular}{lccc}
\hline Question & Responses & Frequency & Percentage \% \\
\hline Do you use you mobile phone to browse internet & Yes & 310 & $83.8 \%$ \\
& No & 60 & $16.2 \%$ \\
Total & & 370 & $100 \%$ \\
\hline
\end{tabular}

The results in table No.4 above shows that majority of the respondents used their mobile to surf the internet (83.8\%) while very few of the respondents (16.2\%) claimed they don't use their mobile phones to surf the internet. However, further investigation reveals that respondents used their mobile phones for various reasons among which they claimed that mobile phones help them to obtain materials for their academic assignments. It helps them to keep current on national and international developments and above all, they use their mobile phones to establish and maintain effective social contacts.

Table 5. Other Reason for Using Mobile Phone

\begin{tabular}{llcc}
\hline Question & \multicolumn{3}{l}{ Pornographic } \\
\hline Does your mobile carry any porn data in it? & Yes & 180 & $48.6 \%$ \\
& No & 190 & $51.4 \%$ \\
& Total & 370 & $100 \%$
\end{tabular}

The results shown in table 5 above reveals that some of our youths use their mobile phones to receive and send out pornographic pictures and information, advancing the reason that pornographic information and pictures help them to broaden their social contacts, help them to acquire sexual and emotional satisfaction and brings about relief from stress. 
Table 6. NBC Regulation of Mobile Phone Usage

\begin{tabular}{|c|c|c|c|}
\hline Question & Responses & Frequency & Percentage \\
\hline \multirow[t]{3}{*}{ Are you aware of NBC'S regulation concerning the use of mobile phones? } & Yes & 000 & $00 \%$ \\
\hline & No & 370 & $100 \%$ \\
\hline & Total & 370 & $100 \%$ \\
\hline
\end{tabular}

According to the result in table No. 6 above people are not aware of any regulation by the National Broadcasting Commission or Nigeria Communication Commission to regulate the use of mobile phone by an individual, stressing that such law would amount to a violation of the individual's private rights. Some of the respondents were of the view that even if there is any law to regulate the use of the mobile phones by individuals such law is of no effect because mobile phones have become a veritable tool for fraudsters who disguise their identities and perpetuate their nefarious acts. Apart from the negative effects of the use of mobile phones by some individual respondents, all agreed that there are some positive effects of mobile phones on the individuals and the society generally as it has aided the process of information and fast data collection and dissemination by professional communicators.

\section{Summary and Conclusion}

The impact of mobile phone technology on Nigerian's broadcast communication policy is felt more in the area of public morality and social value. Things like obscenity vulgarity, pornographic representations, drug addiction, robbery and prostitution are class $\mathrm{A}$ and $\mathrm{B}$ offenses that broadcasters are warned against so as to protect children from distorted views of morality but with the advent of mobile phone communication in Nigeria, these have become persuasive as even children of basic school age now can have access to materials on pornography and related information and facts in pictures and video clips which are electronically transferred using mobile phones.

This study has shown that the penetration of mobile phones in the Nigerian society is rapid, enormous and fast that even children of basic school age owned sophisticated mobile phones with high profile facilitates that can effectively deliver pictures and film clips and other form of data to its target unhindered.

The use of mobile phones as effective medium by fraudsters who disguise their identity to perpetuate their nefarious acts has forced the Nigerian communication commission to come up with a policy asking all telecommunication service providers in the country to ensure that all phone owners registered their SIM cards and obtains their biodata to help check crimes committed through the use of mobile phones.

\section{References}

Adekola, S. A. (1987). Planning Communication System: A Critical Model and Variables. In Nnaemeka, T. et al (eds.) Philosophy and Dimension of National Communication Policy. 2, Illorin: Woye and Sons Press Ltd.

Althans, et al. (2007). Australian Policy Handbook. (4 ${ }^{\text {th }}$ Ed.) Sydney, Australia: Allen and Unwin.

Collier, P. (2002). Policy for post conflict societies: Reducing the risk of renewed conflicts. A Paper presented at the Conference for Economics of Political Violence, Princeton University Centre for International Studies.

Doreen, M. (1993). Power-geometry and A progressive sense of place in Ticker L. (ed) Mapping the Future, Local Cultures, Global Change, New York, Rutledge Press.

Faleti, S. A. (2007). Theories of Social Conflict. In G. B. Shedrack (ed). Introduction to Peace and Conflict Studies in West Africa; Ibadan: Spectrum Books Ltd.

Folarin, B. (1998). Theories of Mass Communication: An Introductory Text. Lagos, Nigeria: Stirling-Horden Publishers Nig. Ltd.

Hagedorn, R., \& Labovits, S. (1973). An Introduction to Sociological Orientation. New York, USA:

Hamelink, C. I. (2002). The politics of Global Communication. In Yahya, R. Kamalipour. (ed). Global Communication. Delmont, USA: Wadsworth/Thomson Learning.

Haralambos, M., \& Heald, R. (1980). Sociology: Themes and Perspectives. New Delhi, India: Oxford University Press.

Howard, C. I. (2005). The Policy Cycle: A model of Post Machiavellian Policy Making. In The Australian Journal of Public Administration. Sydney, Australia: (on-line).

Jenkins, W. (1978). Policy Analysis: A political and Organizational Perspective. London, UK: Martin Robertson.

Kinlock, G. C. (1977). Sociological Theory: Its Devleopment and Major Paradign. New York, USA. 
Kunczik, M. (1984). Communication and social change. Bonn, Germany: Friedrick-Ebert-Stiftung.

Lewis, P. V. (1975). Organizational Communication: the Essence of Effective Management. Ohio, USA: GRID Inc.

Mac Bride, S. (1980). Many Voices One World. Ibadan, Nigeria: UNESCO.

Mc Quail, D. (2005). Mc Quail's Theories of Mass Communication. London, UK: Sage Publication.

Mu'azu, A. (2010). Law, Ethics and Communication: An Overview”. An Unpublished Lecture Note for Postgraduate students of mass Communication, University of Maiduguri.

Murtala, M. (1991). New Media Technologies and Society: An introductory text book for students and jounralists. Kaduna, Nigeria: Nation House Press.

NBC (2006). Nigeria Broadcasting Code (4 ${ }^{\text {th }}$ Ed.). NBC.

Ndidi, I. (ed.) (2005). Dictionary of Mass Communication. Owerri, Nigeria: Book-Konzult.

Ndukwe, E. (2004). The role of Telecommunication in National Development. A paper presented at the $19^{\text {th }}$ Omolayole Annual Management Lecture held December $5^{\text {th }}$ Victoria Island, Lagos.

Omerou, K. (2007). The impacts of GSM mobile phones on Nigerians”. www.gsmusersforum on $21^{\text {st }}$ August, 2010

Paquette, L. (2002). Analyzing National and International Policy. Littlefield: Rowman.

Schiller, H. I. (1976). Communication and Cultural Dormination. White Plain, New York: International Arts and Science Press.

Smith, A. (1980). Geopolitics of Information: How Western Cultures Dominates the World. New York, USA: Oxford University Press.

Telecom-GSM Fundamentals kornadian.cafe24.com/document-srl=270642/telecom-GSM Fundamentals Retrivedfrom www.beginnersguide.com on $21^{\text {st }}$ August, 2010.

Udeajah, R. A. (2004). Broadcasting and Poltiics in Nigeria: 1963-2003; Enugu: SNAAP Press, Ltd.

Udomisor, I. W. (2009). Communication Policy”. An Unpublished Lecture Note for Postgraduate students of mass communication, University of Maiduguri.

Udomisor, I. W. (2012). Communication Policy”. An Unpublished Lecture Note for postgraduate students of mass communication, University of Maiduguri.

What does GSM mean in Cell phone? Electronics.howstuffworks.com/question537.html Retrived from www.howstuffsworks.com on $21^{\text {st }}$ August, 2010.

What is Global System of Mobile Communication? searchmobilecomputing.techtarget.com/definition/GSM Retrived from www.searchmobilecomputing.com on $21^{\text {st }}$ August, 2010.

\section{$(\mathrm{cc}) \mathrm{BY}$}

This work is licensed under a Creative Commons Attribution 3.0 License. 